\section{Social science defended}

SIR-Your leading article "What happened to social science?" (Nature 334, 91; 1988) rightly draws attention to important gaps in the relationship between research and government policy-making. But it is hard to see what basis you can have for your belief that social scientists have "fallen into silence" over serious social issues. Without entering into the comparison you make with their former "vociferousness", it is certainly fair to say that they have been and are working on the issues of social relevance and public interest to which the latter half of your article refers.

Indeed, in each of the areas of social concern you identify, and of course in many others, the Economic and Social Research Council (ESRC) is funding research projects that seek to illuminate issues and provide analysis and recommendations for policy-makers, and a selection of these clearly shows how social scientists are exerting themselves. For example, the work of the Sir Norman Chester Centre for Football Research at the University of Leicester has analysed soccer hooliganism and works closely with the Department of the Environment and the football authorities to produce solutions. The ESRC has also commissioned studies on the problems of alcohol abuse: the Addiction Research Centre at the University of Hull has recently undertaken research for the Department of Health and Social Security on local prevention strategies.

The ESRC has also just started a major programme of research into the social and behavioural aspects of human immunodeficiency virus infection and AIDS, including studies of young people, the behaviour of drug users, the behaviour of bisexual men and the way AIDS is covered in the media. The aim of this research is to provide information on which effective programmes of health education, health policy and other intervention strategies can be based.

A further example is in the ESRCfunded research on the growing discipline of health economics, which is contributing to more effective and efficient health policies. Measures of the effects on health of various treatments, developed at the Centre for Health Economics at the University of York, are now being used within the health services to decide on priorities for courses of treatment.

These are just a few examples of the many important issues that social scientists are addressing with the help of funds from the ESRC. Certainly the council takes, and is addressing, the point that more needs to be done to ensure that social science findings are well disseminated and made available to busy policy-makers in a digestible form. For example, in the autumn, the ESRC is holding a seminar involving policy-makers and academics to discuss how social science research can be better utilized in policy-making. We agree that the impact of research on policy is difficult to assess. There is an active social science research community concerned with policy, results and advice, and there are receptive audiences for their research. They need to be brought closer together and the ESRC is actively working for that improvement.

D.V. STAFFORD (Acting Chairman)

Economic \& Social Research Council, 160 Great Portland Street, London WIN 6BA, UK

SIR-Social science is in disarray not because of government neglect (Nature, 334, 91; 1988) but because it has failed to deliver the goods. The promissory notes of the 1950s and 1960s that social scientists could solve the problems of crime, education, social prejudice, psychopathology and even warfare are unredeemed. Due to inappropriate models of human functioning, the problems have sometimes been exacerbated. The widespread belief that there is no genetic basis by which people differ in important ways so that discipline and punishment are counterproductive, has led to unbenign social policies, research programmes and editorial biases. It is rapidly becoming apparent from breakthroughs in human genome sequencing, behavioural genetics and developmental sociobiology that a very different state of affairs exists, one which has already challenged the way we think about life, and what is right and what is wrong. Until the social sciences 'come to terms' (as their practitioners like to say) with their biophobia and construct truly biosocial models of human functioning, they will continue, and perhaps ought to continue, to languish on the periphery.

Department of Psychology,

J. Philippe Rushton University of Western Ontario, London, Ontario N6A 5C2, Canada

\section{Precinct NIH}

SIR-The detailed analysis of the "Baltimore case" by John Maddox (Nature 333, $795 ; 1988)$ ended on an upbeat note, expressing confidence that the US Congress will no doubt leave it to the scientific community to take care of problems of misconduct in research. We should therefore note the following disquieting statement in the recent bill on National Institutes of Health (NIH) appropriations, approved by the Senate Appropriations Committee: "The committee also expects NIH to strengthen its internal investigative responsibilities and fully explore the possibility of requiring the many peer review panels that evaluate research proposals to also on a random basis evaluate the results of that $\mathrm{NIH}$ sponsored research with a focus on the broad area-of scientific misconduct."

This suggestion seems too fantastic to get very far. Scientists volunteering to serve on review panels would surely be unlikely to welcome the assignment of becoming policemen, to consider it necessary, or to see how to accomplish the goal. Nevertheless as fraud is now being discussed as though it were a major problem in science, and as in the end the power of the purse is virtually unlimited, we cannot be sure. The proposal is certainly worth keeping an eye on.

Bernard D. Davis

Bacterial Physiology Unit,

Harvard Medical School,

25 Shattuck Street,

Boston,

Massachusetts 02115, USA

\section{Space defence}

SIR-D.N. Spergel and G.B. Field (Nature 333, 813;1988) give very persuasive arguments against the cost-effectiveness of space-based interceptor ballistic-missile defence. Such arguments may collapse, of course, if some unexpected new technological breakthrough should develop.

An argument which is less vulnerable to the possibility of such breakthroughs can be based on the fact that there are two possible outcomes of any such defence system with space-based components (SBCs):

(1) Locally concentrated anti-satellite (ASAT) forces could become capable of creating a window (in the necessarily dispersed SBCs) for attacking ballistic missiles to pass through.

(2) The SBCs could somehow be made survivable against ASAT attacks. But then the same space-survivability techniques would make possible at least equally survivable (and therefore unstoppable) nuclear orbit-to-Earth missiles (NOEMs), which would give much less warning time than ballistic missiles when launched against ground targets.

In either of these two scenarios, the defences would be overcome.

Early versions of NOEMs were tested by the Soviets in the 1960s. They are currently banned by the 1967 Outer Space treaty, but Gorbachev warned at the 1985 summit that all arms control "will be blown to the winds" if a ballistic-missile defence with SBCs (banned by the AntiBallistic Missile treaty) is deployed.

LOUIS A.P. BALÁzS

Theoretical Physics Group, 50A-3115,

Lawrence Berkeley Laboratory,

Berkeley, California 94720, USA 